Canadian Journal of Higher Education

Revue canadienne d'enseignement supérieur

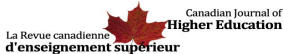

\title{
Owen-Smith, Jason (2018). Research Universities and the Public Good: Discovery for an Uncertain Future
}

\section{Daniel Wallace Lang}

Volume 49, Number 2, 2019

URI: https://id.erudit.org/iderudit/1063782ar

DOI: https://doi.org/10.7202/1063782ar

See table of contents

Publisher(s)

Canadian Society for the Study of Higher Education

ISSN

2293-6602 (digital)

Explore this journal

Cite this review

Lang, D. (2019). Review of [Owen-Smith, Jason (2018). Research Universities and the Public Good: Discovery for an Uncertain Future]. Canadian Journal of Higher Education / Revue canadienne d'enseignement supérieur, 49(2), 109-113. https://doi.org/10.7202/1063782ar 


\section{CSSHE SCÉES}

Canadian Journal of Higher Education Revue canadienne d'enseignement supérieur

Volume 49, No. 2, 2019, pages 109 - 113

\section{Book Reviews / Comptes Rendus}

Owen-Smith, Jason (2018). Research Universities and the Public Good: Discovery for an Uncertain Future. Palo Alto: Stanford University Press. Pages: 232. Price: $\$ 35.00$ USD (hardcover).

Reviewed by Daniel W. Lang, Emeritus Professor, University of Toronto.

Research Universities and the Public Good: Discovery for an Uncertain Future in several respects conveys a different message for a Canadian audience than for an American audience. "Public" is a qualifier within American higher education because the United States, unlike Canada, is a "mixed jurisdiction" comprising private research universities as well, which, Owen-Smith would say, have a share in the "public" research mission. The American Association of Universities is a good proxy for what Owen-Smith means by "research university." The AAUs membership splits nearly 50-50 between public and private. The AAU has two Canadian members. Owen-Smith's threshold for "research university" status is \$100 million ( $\$ 133$ million CND) in sponsored research income. Fifteen Canadian universities meet that benchmark. Although, taking private sector spending and public sector spending together, the United States spends much more in total than Canada on research and development, Canadian universities perform a larger proportionate share of all research and development undertaken 
within the country than do their American counterparts. In that sense, in Canada, Owen-Smith is preaching to the converted. Although the recent report of the Advisory Panel for the Review of Federal Support for Fundamental Science [Naylor report] recommended increases in funding for university research, the purpose of the increase was not to change the share of research and development conducted by universities.

The peculiar capability of highly research intensive universities to promote the public good rests, according to Owen-Smith, on a heterogeneous composition of four elements: networking, collaboration, focal hubs, and campuses as entrepot "anchors" for a wide variety of private and public sector researchers, scholars, and public intellectuals. He also attributes their strength to concentration, and argues that research funding should be awarded partly on the basis of research intensity. That, evidently, is the basis of the $\$ 100$ million threshold. At the same time, however, Owen-Smith assigns a special economic impact role for research universities as regional "anchors," as if top-tier research universities share a systematic geography. How these last two attributes, which seem to be at cross-purposes, can coexist is not explained. That question has relevance in Canada because the federal research councils, including the Canadian Foundation for Innovation, have from time to time attempted to do both.

Much of Owen-Smith's previous scholarship is highly datadriven. In the case of Research Universities and the Public Good: Discovery for an Uncertain Future, however, none of these assertions is accompanied by hard evidence. One wonders, for example, why smaller, less research intensive universities are not capable of offering heterogeneity, inter-sector collaboration, and economic spillover to their regions. That this question is not resolved is surprising because Owen-Smith was a co-investigator in two studies that demonstrated the spillover effects of university research and development spending on local economies (Chhabra, Levenstein, \& Owen-Smith, 2018; Owen-Smith \& Powell, 2004). Canadian readers might recall the "centres of excellence" model. 
The book pays more attention to the university campus, including architecture, as a physical pollinator than a reader might expect. The discussion is interesting; for example, an academic "stoa as knowledge generator" case is based on a study of walking paths. The case is persuasive until the reader discovers that the study was based on paths within single buildings, not an entire campus. The take-away from this might be that the assignment of space is more important than architecture. It also might be that smaller, more physically compact universities might promote networking more than large mega research universities.

Research Universities and the Public Good: Discovery for an Uncertain Future presents a strong case for the capacity of research universities to innovate and discover in service to the public good, for directing more public financial support to them, and for ensuring their fiscal stability and "fixity,"by which he seems to have in mind the research university as a public utility. Owen-Smith presents the market argument for diversifying funding for research universities to include private support. His analysis of the argument comes down against it. The analysis is on one hand persuasive in respect to the threats and problems that it identifies. On the other hand, the analysis is incomplete, for example, by not giving due regard to steering effects on the precarious balance between basic research and targeted applied research, and to the prospect of access to less funding. Regardless of its outcome, the public utility argument is an aspect of the book that is well worth reading by Canadians, especially policy-makers, because it addresses an issue that is as prevalent in Canada as in the United States.

Owen-Smith is a strong advocate for what in Canada is called "core" funding, and the inseparability of resources for research and instruction. Following that, a case is also made for the quality and distinctiveness of instruction provided by research universities: Research universities are not only better at research, they are also better at instruction. This is an argument that has gained less traction in Canada than in the United States, although, even there, elite liberal arts colleges challenge the proposition. The instructional case 
is made less strongly, and without acknowledgement of evidence to the contrary, especially evidence that the instructional Peter is often robbed to pay the research Paul (Gillen, Denhart, \& Robe, 2011). Owen-Smith acknowledges that such "cross subsidies" exist in research universities, including his own. Weak or strong, OwenSmith's case against "unbundling" core funding begs a question about contrary evidence. Many American research universities systematically separate spending on instruction and research. A few Canadian universities do too. Unlike in Canada, funding for the indirect costs of research in the United States flows separately from funding for instruction. The question left hanging is how have American research universities become leaders in innovation and discovery in a system that is already "unbundled"to such a large extent, especially when the institutional component is of their own making?

From a Canadian perspective, is Research Universities and the Public Good: Discovery for an Uncertain Future worth reading? Generally, no. Although the report of the Advisory Panel for the Review of Federal Support for Fundamental Science is less felicitous, it provides a better, more informed, and more incisive insight into many of the same issues that Owen-Smith takes up. It, for obvious reasons, is more relevant. For certain audiences, however, the answer might be yes, or at least maybe. Most of Canada's research intensive universities compete for American sponsored research funding, and account for it as their American counterparts do. Much of what the book says about public American research universities can be applied to them.

\section{References}

Chhabra, Y., Levenstein, M., \& Owen-Smith, J. (2018). Local fiscal multiplier on $R \& D$ and science spending: Evidence from the American recovery and reinvestment. Ross School of Business Working Paper No. 1383, University of Michigan.

Gillen, A., Denhart, M., \& Robe, J. (2011). Who subsidizes 
whom? Washington, DC: Center for College Affordability and Productivity.

Owen-Smith, J., \& Powell, W. W. (2004). Knowledge networks as channels and conduits: The effects of spillovers in the Boston biotechnology community. Organization Science, 15(1), 5-21. 